\title{
The Impact of Tourism and The Creative Industry on The Economy of The Community
}

\author{
Herie Saksono $^{1}$, Bachtari Alam Hidayat ${ }^{2, *}$, Evi Yuliana ${ }^{3}$, Baskoro Wicaksono ${ }^{4}$, Afriyanni $^{5}$, \\ Sekar Nur Wulandari ${ }^{6}$, Momon Momon ${ }^{7}$, Kusmawaty Matara ${ }^{8}$, and Nanda Hasanul Amri ${ }^{1}$
}

${ }^{1}$ Research \& Development Agency of the Ministry of Home Affairs of the Republic of Indonesia, Jakarta, 10430, Indonesia

${ }^{2}$ Development Planning, Research and Development Agency of Palembang City, 30131 and Pascasarjana Universitas

Tamansiswa Palembang, South Sumatera Province, 30126, Indonesia

${ }^{3}$ Development Planning, Research and Development Agency of Palembang City, South Sumatera Province, 30131, Indonesia

${ }^{4}$ Universitas Riau, Riau Province, 28293, Indonesia

${ }^{5}$ Research and Development Agency of Pekanbaru City, Riau Province, 28285, Indonesia

${ }^{6}$ Planning, Research and Development Agency of Riau Islands Province, 29124, Indonesia

${ }^{7}$ Research and Development Agency of West Sumatera Province, 24125, Indonesia

${ }^{8}$ Institut Agama Islam Negeri (IAIN) Sultan Amai Gorontalo, Gorontalo, 96114, Indonesia

*Corresponding author E-mail: alamhidayat79@gmail.com

\begin{abstract}
Local culture has remained a valuable commodity and activity for attracting tourists up to the present day. Tourism development is also aided by the creative sector, which is a component of the creative economy, which is intended to become a new engine for the national economy. Culinary art is exceptional in the creative industry sector since it has a significant multiplier effect on the industry's growth. This study employs a qualitative methodology in conjunction with a phenomenological research plan. Primary data were gathered through in-depth interviews with tourism industry participants and competent tourism officials. Culinary goods in Palembang are classified into two categories: traditional culinary and modified culinary. There are 50 classic culinary locations and 45 modified culinary locations, each with a unique distribution map. While the traditional culinary district is concentrated around the Musi River, the modified culinary district is scattered more equally throughout the urban region. Of course, the ingenuity of this program provides an alternate solution to the city of Palembang's economic challenges. Palembang's Malay community controls the pempek industry. There are between 50 and 60 culinary service companies in Area 26 Ilir. The site is advantageous because it is close to the city core and the hub of Musi River tourist activities. The existence of pempek as a creative product is strategically important because it is psychologically and economically capable of multiplying the culinary market circulation in Palembang. The multiplier effect can be seen from visiting interest and tourist spending, investment, government financing in the culinary industry which has an economic impact in the form of increased output, added value, increased income, and the creation of manpower as well as an increase in regional original income (PAD) in South Sumatra.
\end{abstract}

Keywords : Tourism city, creative industry, and people's economy

\section{INTRODUCTION}

Tourism is a significant component of both the national and regional economies $[1,2,3,4]$. Tourism contributed 5.25 percent to the country's Gross Domestic Product in 2018 [5]. Tourism development is also aided by the creative sector, which is a component of the creative economy [6]. The creative economy sector, which is built on creativity and innovation, is predicted to become a new force in the national economy by 2020 [5] and to contribute to the national and regional economies [8, 9]. In 2018, the creative industry sector contributed IDR 800 trillion to GDP, or $8 \%$ of overall Gross Domestic Product (GDP), growing at a rate of 5\% per year [6].

Local culture has remained a valuable commodity and activity for attracting tourists up to the present day. Additionally, the shift in travel motive, which is no longer primarily focused on products or services but rather on the trip experience, fosters the growth of gastro-tourism [10, 11]. Gastronomy, also known as culinary art, is one of the indigenous cultures in the confectionery industry that has emerged as a new tourism draw. Gastronomy is a crucial component of tourism because it enables visitors to learn about the cultural legacy of the locations they visit [12].

Culinary art is exceptional in the creative industry sector because following the craft and fashion sectors, it has a significant multiplier effect on the development of the creative industry [13]. Gastronomic tourism has a substantial positive effect on destination loyalty and visitor satisfaction $[12,14,15,16]$. Certain tourist locations rely on gastronomy to attract visitors, while others use tourism to promote their country's cuisine.

Gastronomic resources mixed with a destination's cultural essence have become a major attraction for travelers. The culinary triad of food, culture, and tourism will have an impact on society's grassroots level in terms of social and economic survival, as well as the marketing of tourist attractions. When viewed through the lens of marketing, this field presents a wonderful opportunity to advertise specific 
tourist locations [12]. The plan for prioritizing the gastronomic trio approach can be viewed as a new dimension in which culinary, cultural, and tourism activities all play a strategic role in destination promotion, hence improving regional creative sector income through economic diversification [12]. As a result, it has a significant impact on the economic development of the local community [17].

Certain research findings indicate a shift in the behavior of tourists who prefer to sample local confectionery and vice versa. In the modern era, a destination's culinary culture serves as the bedrock of the tourism phenomena [18]. Due to the popularity of culinary culture and its contribution to a region's socioeconomic stability, the scope of the global cultural tourist event has broadened [12]. Food and culture are inextricably linked throughout the year, providing the best opportunity for travellers to enjoy both. Collaboration between gastronomy, culture, and tourism is a new trend that emerges and thrives in a certain tourist location. The gastronomy trio is critical for its ethical and sustainable values, which are founded on indigenous food, culture, customs, lifestyles, and activities that attract visitors and encourage destination marketing. The gastronomy triad is a journey of meaningful experience that comprises exploring with and tasting new foods and beverages, learning about other cultures, lifestyles and traditions, acquiring expertise from hosts, and engaging guests through destination marketing processes.

Palembang is a tourist destination known for its abundance of natural beauty, culture, history, and gastronomic diversity. Tourism is the region's largest industry, accounting for over 30\% of Local Revenue (PAD) in 2019, positively improving people's living standards, and boosting job prospects. The expansion of the tourism business is accompanied by the expansion of a distinct culinary creative industry, which serves as a magnet for tourism promotion. The purpose of this paper is to discuss the gastronomic trilogy's potential and the growth of the creative culinary sector in Palembang City, as well as the impact on the regional economy.

\section{METHODS}

This study employs a qualitative methodology in conjunction with a phenomenological research plan. Primary data were gathered through in-depth interviews with tourism industry participants and responsible tourism officials. Additionally, field observations were made. The data were evaluated in a non-statistical manner by providing methodical, factual, and precise representations of the facts pertaining to the tourism dynamics in Palembang City. Secondary data is gathered from government agencies such as the Palembang City Government and the Palembang City Central Bureau of Statistics.

\section{RESULTS AND DISCUSSION}

Palembang is a city on the Musi River that is rich in natural, cultural, and culinary resources as a result of Chinese, Arabic, Indian, and Malay acculturation [19]. The confluence of Musi Riverside's natural resources, culture, and cuisine is marketed through Palembang City Tourism's City branding, "The City Where Culture and River Meet in Harmony." The term refers to a city in which culture and river coexist harmoniously to generate beauty [20].

The Musi River separates Palembang into two halves, upstream and downstream, which are united by the Ampera bridge. The area downstream serves as the city and government core, while the portion upstream is residential. The Musi River area is more strategically located because it is a hub of human activity and offers tourism potential. The area along the Musi River has established a tourism potential for religious, historical, water, and shopping tourism [21]. The Musi River Festival and the Bidar Competition are held in this area. Additionally, Musi Tour activities exist, which include cruises on tourist boats that visit tourist spots along the Musi Riverside. Along with cultural attractions, the area along the riverfront is home to numerous tourist attractions, including the Ampera Bridge, Benteng Kuto Besak, Sultan Mahmud Badaruddin II Museum, Pulau Kemaro, and Pasar Ilir 16.

Coordination of poverty alleviation programs, namely the New Entrepreneur Growth Program and the empowerment of micro and small businesses is necessary [22]. A souvenir market and a food market were created to promote tourism activities [23]. Since the culinary industry is classed as a monopolistic market with a large number of buyers and sellers, product differentiation is required [24]. Culinary goods in Palembang are classified into two categories: traditional culinary and modified culinary. According to data from the Palembang City Tourism Office, there are 50 traditional culinary destinations and 45 modified culinary locations, each with a unique distribution map. The traditional culinary area is focused along the Musi River, while the modified culinary area is more evenly distributed throughout the urban area. Of course, the creativity of this policy is an alternative solution to the people's economic problems in Palembang City [25].

Palembang's culinary diversity is a result of the acculturation of Chinese, Arabic, Indian, and Malay cultures through food, and the city has developed into a center for traditional culinary snacks in Indonesia [19]. For instance, martabak cele is influenced by Indian culture, fried bread and pempek by Chinese culture, and nasi lemak by Arabic culture. Pempek is one kind of acculturated cuisine that has developed into a culinary symbol in Palembang. This sort of food has grown into a large-scale culinary sector, which is concentrated in the downstream pempek 26 and 27 industrial districts.

Palembang's Malay population controls the pempek industry. There are 50-60 culinary service providers in the downstream area of 26. The location is advantageous because it is close to the city center and the Musi River tourism hub. The downstream 27 area is partly pempek collectors to areas around Palembang, such as Baturaja OKU, Indralaya, and Tanjung Enim. This area not only sells pempek, but also traditional culinary delights that are becoming increasingly scarce in modern times, such as rendang bread, fried bread, and a steamed bun stuffed with tenten, kamer, and dadar jiwo.

The Gastronomy Trilogy (culture, tourism, and gastronomy) has developed into a major draw for travelers visiting Palembang. From a nation of origin perspective, the biggest proportion of foreign visitors visiting South Sumatra 
between 2012 and 2019 were Malaysians (56 percent), Singaporeans (11\%), Chinese (3 percent), and South Koreans ( $1 \%$ ), while the rest of the $29 \%$ originated from countries that cannot be identified in detail (Diagram 1). In terms of visitation, the majority of foreign visitors visiting South Sumatra are Malaysian, followed by Singaporeans. Geographical, demographic, and cultural considerations all contribute to the two countries' crowded homesteads.

Figure 1. Number of Foreign Tourist Visits to South Sumatra in 2012-2019

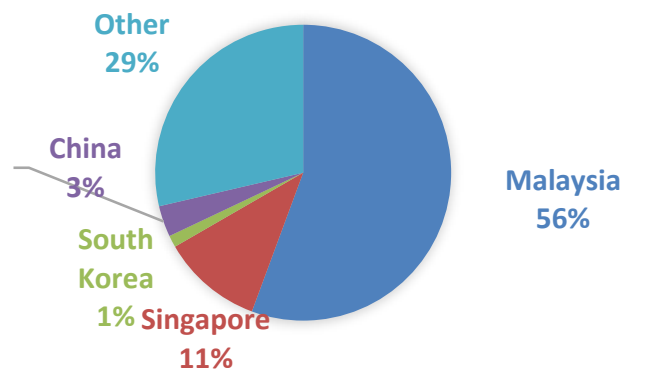

Source :http://satudata.sumselprov.go.id, data accessed on 26 September 2021

This tourism potential contributes to an increase in tourist visits to Palembang. In 2014, Palembang City welcomed $1,828,207$ tourists, including $1,817,346$ domestic visitors (99.41 percent) and 8,861 overseas visitors ( 0.59 percent). Despite the smog and political turbulence that year, the number of domestic and foreign visitor visits to Palembang climbed by 2.34 million in 2019. This increase is attributed to the relatively easy accessibility of air transportation [26], with Sultan Badaruddin Airport in Palembang City connected to two international routes (Singapore and Malaysia) and 17 domestic routes, including Bali, the most popular destination for foreign tourists. According to data from the City of Palembang's Central Statistics Agency, foreign tourist visits to South Sumatra reached 15,846 in 2019, an increase of 14.31 percent over the same period in 2018. Only 13,862 visits came through Palembang's Sultan Mahmud Badaruddin II Airport. The increasing number of tourist visits contributed to the three business sectors as presented in Table 1.

Table 1. Contribution of Main GRDP Sector by Business Field in Palembang City, 2016 to 2020

\begin{tabular}{|l|c|c|c|c|c|}
\hline \multirow{2}{*}{ GRDP Sector } & \multicolumn{5}{|c|}{ Contribution (\%) } \\
\cline { 2 - 6 } & $\mathbf{2 0 1 6}$ & $\mathbf{2 0 1 7}$ & $\mathbf{2 0 1 8}$ & $\mathbf{2 0 1 9}$ & $\mathbf{2 0 2 0}$ \\
\hline $\begin{array}{l}\text { Processing } \\
\text { industry }\end{array}$ & 33,48 & 33,1 & 33,2 & 31,36 & 32,26 \\
\hline Construction & 18,27 & 18,35 & 18,37 & 17,89 & 17,19 \\
\hline $\begin{array}{l}\text { Wholesale and } \\
\text { Retail Trade; } \\
\text { Car and bicycle } \\
\text { repair }\end{array}$ & 15,22 & 15,74 & 16,68 & 17,41 & 17,51 \\
\hline
\end{tabular}

Source : Central Bureau of Statistics of Palembang City (2018)

Table 1 shows that manufacturing is the primary contributor to Palembang City's GRDP. On the other hand, food and beverage processing has an effect on the development of the culinary market structure due to the low entry barrier, ease of licensing, and access to the food and beverage market for new business actors; capital requirements are not prohibitively high, and business processes are straightforward. In addition, the culinary industry sector can absorb a lot of workers to overcome the problem of unemployment which is one of the causes of poverty in Palembang [27].

The existence of pempek as a creative product is important because it has a multiplier effect on the circulation of the culinary market in Palembang City, both mentally and commercially. Visitor interest and tourist spending, investment, and government finance in the culinary industry all have an economic impact on South Sumatra in the form of increased output, added value, income, and job creation, as well as an increase in local revenue (PAD).

\section{CONCLUSIONS}

Palembang City's cultural, tourist, and culinary diversity may be controlled through evidence-based policies that are implemented with the local government's political commitment. The culinary business is a one-of-a-kind creative economy product with a strong appeal to destination loyalty, which is a critical component of tourist promotion. Palembang City's extraordinary culinary industry should be developed through a strategy of product differentiation, assistance, and collaboration and partnership between the government, academia, the tourism community, the media, and society, all of which are based on innovation and the use of digital technology.

\section{REFERENCE}

[1] Musaddad, A. A., Rahayu, O. Y., Pratama, E., Supraptiningsih, \& Wahyuni, E. 2019. Pariwisata Berkelanjutan di Indonesia. Dinamika Administrasi: Jurnal Ilmu Administrasi Dan Manajemen, 2(1), 73-93.

[2] Sin, K.Y., Kian, T.S., \& Wei, C.S. 2017. A Review on Cultural and Creative Matters. Internationa Journal of Innovation and Business Strategy (IJIBS), 8(2), 40-46.

Sri Widari, D.A.D. 2020. Kebijakan Pengembangan Pariwisata Berkelanjutan: Kajian Teoretis Dan Empiris. Jurnal Kajian Dan Terapan Pariwisata, 1(1), 1-11. https://doi.org/10.53356/diparojs.v1i1.12

[4] Liu, H., \& Wang, B. 2021. Effects of tourism development on economic growth: An empirical study of China based on both static and dynamic spatial Durbin models. Tourism Economics,

$X X(X)$. https://doi.org/10.1177/13548166211021175

[5] Kementerian Pariwisata dan Ekonomi Kreatif Republik Indonesia. 2020. Laporan Kinerja Kementerian Pariwisata Tahun 2019. Kementerian Pariwisata dan Ekonomi Kreatif Republik Indonesia.

[6] Indrajaya, T., Cahyandito, M. F., Wiweka, K., \& Adnyana, P. P. 2019. The Development of Creative Industry Strategies as a Tourist Attraction in Banten Province, Indonesia. 22(5), $1-10$. https://doi.org/10.9734/JEMT/2019/v22i530101

[7] Amin, C., \& Sholahuddin, M. 2020. The Mapping of Creative Economy for the Sustainable Development Goals : A Case 
in Sukoharjo Regency, Central Java, Indonesia. Irceb 2018 , 293-296. https://doi.org/10.5220/0008787202930296

[8] Kovačević, I., \& Anić, A. 2019. Economic Impact of The Creative Indsustry and The Example of Serbia. 008, 522531. https://doi.org/10.5937/EKOPRE2008522K

[9] Lestari, B., Zaini, A., \& P, I. R. 2020. Creative Industries and Their Impact on Regional Competition. 136(Ambec 2019), $165-168$

[10] Williams, H. A., \& Yuan, J. J. 2019. Attributes Of Memorable Gastro- Tourists ' Experiences. 43(3), 327-348. https://doi.org/10.1177/1096348018804621

[11] Martínez de Albeniz, I. 2021. In praise of complexity: From gastronomy to gastrology. International Journal of Gastronomy and Food Science, 25(March), 1-8. https://doi.org/10.1016/j.ijgfs.2021.100360

[12] Mora, D., Solano-Sánchez, M., López-Guzmán, T., \& MoralCuadra, S. 2021. Gastronomic experiences as a key element in the development of a tourist destination. International Journal of Gastronomy and Food Science, 25 (July). https://doi.org/10.1016/j.ijgfs.2021.100405

[13] Astuty, E., Rahayu, A., \& Wibowo, L. A. 2018. Soft Innovation Strategy as a Booster in The Creative Industry( Survey at Bandung as Creative City in Indonesia ). 3040 3049

[14] Fitrizal, Elfiswandi, \& Sanjaya, S. 2021. The impact of culinary tourism on tourist satisfaction and destination loyalty: Padang city, West Sumatra context. 14(1), 135148

[15] Mulyana, A., Ayuni, D., \& Terbuka, U. 2019. Modeling Service Quality: The Impacts of Visitor Loyalty on Culinary Tourism. REview of Integrative Business and Economics Research, 8(1), 47-63.

[16] Rousta, A. 2020. Food tourism value: Investigating the factors that influence tourists to revisit. 26(1), 73-95. https://doi.org/10.1177/1356766719858649

[17] Mehul Krishna Kumar, G. 2019. Gastronomic tourism A way of supplementing tourism in the Andaman \& Nicobar Islands. International Journal of Gastronomy and Food Science, $16, \quad 100139$. https://doi.org/10.1016/j.ijgfs.2019.100139

[18] Seyitoğlu, F., \& Ivanov, S. 2020. A conceptual study of the strategic role of gastronomy in tourism destinations. International Journal of Gastronomy and Food Science, 21(June). https://doi.org/10.1016/j.ijgfs.2020.100230

[19] Oktrina, F. D., Idris, M., \& Suriadi, A. 2021. Tinjauan Histroris Akulturasi Budaya dalam Kuliner Palembang sebagai Sumber (Adriyanto (ed.); 1st ed.). Penerbit Lakeisha

[20] Dama, M. S. D., Fatih, A. Al, \& Melinda, N. 2019. City Branding Pariwisata Kota Palembang (Studi Dinas Pariwisata Kota Palembang Tahun 2018). Universitas Sriwijaya.

[21] Rahmawati, Rizki'Oktarini, M. F., \& Lussetyowati, T. 2021. Perencanaan dan PErancangan PAsar Oleh-oleh dan Pusat Kuliner di Palembang. Universitas Sriwijaya.

[22] Hidayat B.A. 2021. Stunting And Poverty Management Strategies In The Palembang City, Indonesia. Randwick International Of Social Science (Riss) Journal. Vol.2 No. 1 P 86-99

[23] Juliana. 2019. Analisis Potensi Kawasan Wisata Kuliner Dalam Mendukung Pariwisata Di Kota Tegal Jawa Tengah. Jurnal Khasanah, 10(2), 2-3.

[24] Kartika, M. 2018. Pemetaan Ekonomi Kreatif Subsektor Kuliner di Kota Pontianak. 58-71.

[25] Saksono, Herie. 2012. Creative Economy: New Talents for Regional Competitiveness Triggers. Jurnal Bina Praja. Vol.
4 No. 2 Juni 2012: 93-104.

[26] Khana, S.A.R., Qianli, D., Boa, W.S., Zaman, K., \& Zhang, Yu. 2017. Travel and tourism competitiveness index: The impact of air transportation, railways transportation, travel and transport services on international inbound and outbound tourism. Journal of Air Transport Management, Vol $58: 125-134$.

[27] Hidayat, B. A., \& Erlyn, P. 2021. Policy Handling Covid-19 and Effects of Pandemic on Workers in Palembang City. Konfrontasi Journal: Culture, Economy and Social Changes, 8(1). 